\title{
Editorial: Field Data, Models and Uncertainty in Hazard Assessment of Pyroclastic Density Currents and Lahars: Global Perspectives
}

\author{
Pablo Tierz ${ }^{1 \star}$, Andrea Bevilacqua ${ }^{2}$, Stuart Mead ${ }^{3}$, Elaine Spiller ${ }^{4}$ and Laura Sandri ${ }^{5}$ \\ ${ }^{1}$ British Geological Survey, The Lyell Centre, Edinburgh, United Kingdom, ${ }^{2}$ Istituto Nazionale di Geofisica e Vulcanologia, Sezione \\ di Pisa, Pisa, Italy, ${ }^{3}$ Volcanic Risk Solutions, Massey University, Palmerston North, New Zealand, ${ }^{4}$ Department of Mathematical \\ and Statistical Sciences, Marquette University, Milwaukee, WI, United States, ${ }^{5} /$ stituto Nazionale di Geofisica e Vulcanologia, \\ Sezione di Bologna, Bologna, Italy
}

Keywords: volcanology, volcanic hazard assessment, uncertainty, pyroclastic density currents (PDCs), lahars

Editorial on the Research Topic

Field Data, Models and Uncertainty in Hazard Assessment of Pyroclastic Density Currents and Lahars: Global Perspectives

Pyroclastic density currents (PDCs, e.g., Sparks et al., 1978; Branney and Kokelaar, 2002; Sulpizio et al., 2014; Dellino et al., 2019) and lahars (e.g., Manville et al., 2009; Vallance and Iverson, 2015; Thouret et al., 2020) are two of the most destructive volcanic phenomena. They can generate enormous losses of life (e.g., Auker et al., 2013; Baxter et al., 2017; Brown et al., 2017), as well as extensive structural damage to buildings and infrastructure within tens of kilometers from their source (e.g., Valentine, 1998; Baxter et al., 2005; Jenkins et al., 2015). Hazard assessments of PDCs and lahars represent the foundation for estimating the substantial risk that these volcanic mass flows pose to the human environment.

Unfortunately, these hazard assessments are complicated by the spatio-temporal complexity associated with the processes of triggering, propagation (including flow transitions) and emplacement of PDCs and lahars (e.g., Iverson, 1997; Pierson and Major, 2014; Dufek et al., 2015; Dufek, 2016). This natural variability (or aleatory uncertainty), alongside incomplete and imperfect knowledge (or epistemic uncertainty, cf. Woo, 1999; Connor et al., 2001; Marzocchi et al., 2004; Sparks and Aspinall, 2004; Marzocchi and Bebbington, 2012) should ideally be incorporated into the mass-flow hazard assessment (e.g., Bayarri et al., 2009, 2015; Sandri et al., 2014, 2018; Spiller et al., 2014; Neri et al., 2015; Mead et al., 2016; Tierz et al., 2016, 2017, 2018; Bevilacqua et al., 2017, 2019; Mead and Magill, 2017; Wolpert et al., 2018; Hyman et al., 2019; Rutarindwa et al., 2019). At the core of any volcanic hazard assessment resides the volcanological knowledge available for the volcano of interest and/or analogous ones, including information about the sources of uncertainty (e.g., Newhall and Hoblitt, 2002; Aspinall et al., 2003; Sandri et al., 2012; Pallister et al., 2019; Tierz et al., 2019, 2020; Cioni et al., 2020).

In this Research Topic (RT), we have attempted to gather and showcase volcanological expertise from around the globe, related to any component of PDC and lahar hazard assessment: i.e., volcanological field data collection, analysis and interpretation; experimental and/or numerical and/or statistical modeling, including uncertainty quantification. Volcanic systems in 12 countries and 6 continents have been studied (Figure 1A). Below, we summarize the main findings of each article, highlighting the most relevant methodological and volcanological aspects.

Zhao et al. provide a thorough description of the characteristics and spatial distribution of PDC lithofacies, including systematic changes with distance from the vent and topography of the volcanic edifice, associated with the VEI 7 Millennium eruption (946 AD) of Tianchi volcano (China-DPR 


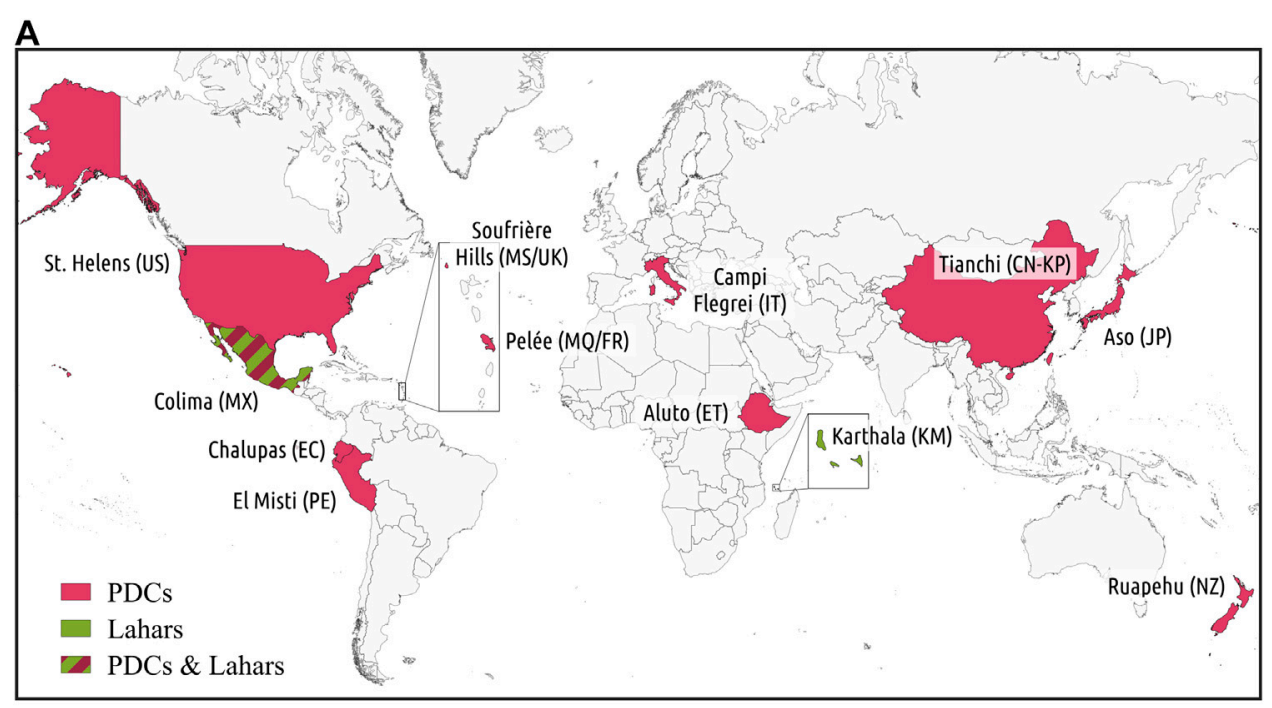

B

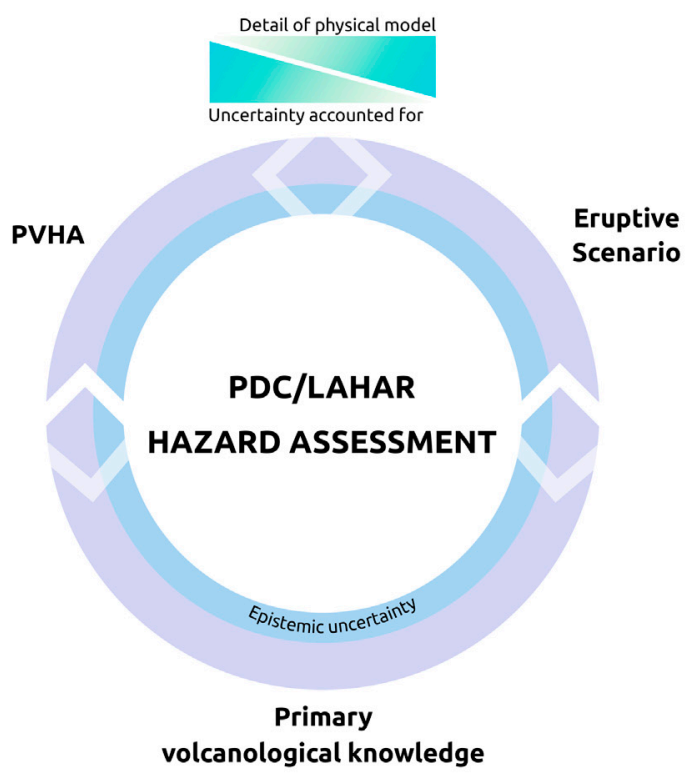

FIGURE 1 | Summary of present and future global perspectives in the field of volcanic hazard assessment of pyroclastic density currents (PDCs) and lahars derived from this Research Topic. (A) Global distribution of countries where volcanic systems have been analyzed in the Research Topic, divided according to whether the main object of study were PDCs or lahars (NB. Two different studies, one for PDCs, Patra et al., and another for lahars, Walsh et al., were presented for Volcán de Colima, Mexico). Map generated using Quantum Geographical Information System (QGIS Development Team, 2021), and Eurostat GISCO Geodata ( ${ }^{\circ}$ EuroGeographics for the administrative boundaries, 1:3 Million Scale. Downloaded January 25, 2021). (B) Interrelationships between three main approaches commonly used in volcanic hazard assessment of PDCs and lahars. One is based on collating fundamental volcanological knowledge for the volcanic system of interest (and/or analogue volcanoes). Both scenario-based as well as probabilistic volcanic hazard assessments (PVHA) build upon this primary volcanological knowledge. Currently, there is a balance between the degree of physical detail and the uncertainty accounted for that can be achieved with scenario-based and PVHA methods. We argue that the three approaches are complementary and mutually beneficial, and that they should be increasingly merged in future hazard assessments. We also stress the key importance of acknowledging the presence of epistemic uncertainty on all three approaches, and of trying to quantify it as best as possible.

Korea border). The work underlines the significant PDC hazard from past (and future) eruptions at Tianchi, and recalls the notable thermal hazard of PDCs.
Takarada and Hoshizumi re-evaluate the distributions and eruptive volumes of large-scale PDC (up to $166 \mathrm{~km}$ runout) and tephra fall deposits derived from the caldera-forming Aso-4 eruption 
(87-89 ka) of Aso volcano (Japan). The total eruptive volume of the Aso-4 eruption is about 1.5-3 times larger than the previous estimation, making it now a M8.1-8.4 (VEI 8) super-eruption.

Silleni et al. develop a new isopach-based method to estimate (large-magnitude) ignimbrite volumes, using extrapolations of the pre-eruption topography to better constrain epistemic uncertainty. The method should be reproducible for other topography-controlled ignimbrites and, applied to the M7 Campanian Ignimbrite eruption $(\sim 40 \mathrm{ka})$ of Campi Flegrei caldera (Italy), significantly reduces the epistemic uncertainty in total erupted volume compared to previous estimates.

Gillies et al., by means of a comprehensive field-mapping at Mt. Ruapehu volcano (New Zealand), have identified 12 new PDC deposits from at least 10 previously unknown flows. Concentrated-flow behavior and the approximate age ranges of these flows were inferred from lithofacies, stratigraphy and whole-rock geochemistry. The article highlights the capability of Mt. Ruapehu to generate different sizes and styles of PDCs, a key element for future hazard planning.

Gilbertson et al. propose an alternate mechanism for secondary hydroeruptions in PDC deposits. Analogue experiments suggest hydroeruptions are possible where lowpermeability (fine-grained) beds are capped by highpermeability (coarse-grained) beds through a drag-based mechanism. Gas pockets and explosive failure may occur if gas flow supports fluidization of the fine, but not coarse particles. This expands the range of physical mechanisms for a secondary hazard often poorly represented in the geologic record.

Walsh et al. analyze lahar dynamics using a 3-component, broadband seismometer at Volcán de Colima (Mexico). The study argues the merits of utilizing all three seismic components to analyze the spectral content of ground motion parallel to and across the drainage channel. They further relate these seismic analyses to the flow rheology and physical processes of the observed lahars.

Córdova et al. combined fieldwork, laboratory, remote-sensing and numerical-modeling techniques to infer the relation between a hummocky field at Chalupas caldera (Ecuador), and the partial collapse of the post-caldera Buenavista lava dome. The work evidences the advantages of integrating classical and modern techniques for the interpretation of volcanological phenomena, and sheds light on the directionality, timing and approximate volume of the associated breccia flow.

Dille et al. tested the effectiveness of two flow models for simulating rain-triggered lahars at Karthala volcano, Grand Comore Island. Karthala has a lower gradient and poorly incised channels that can limit the reliability of models compared to stratovolcanoes. Field methods to improve the Digital Elevation Model (DEM) and constrain inputs improved accuracy of the results. This article demonstrates approaches that may improve hazard assessment accuracy in difficult-to-model settings.

Gueugneau et al. numerically investigate the Mount Pelée May 8th, 1902 pyroclastic current, using a two-phase model that simulates both the block-and-ash flow and the ash-cloud surge. The study discusses conflicting interpretations of the pyroclastic current dynamics, either a blast related to a laterally oriented dome explosion or an ash-cloud surge derived from the block-and-ash flow.
Charbonnier et al. conducted a multi-disciplinary study on the PDCs generated by El Misti volcano (Peru) in its reference eruption for hazard assessment in Arequipa ( $>1 \mathrm{M}$ residents). Combining new field-mapping with a 2-m resolution DEM, they re-assessed the area invaded by PDCs and their total bulk volume. The latter is used in the VolcFlow model to assess the probability of similar PDCs impacting specific valleys, which is key to understand potential effects of PDCs on Arequipa.

Patra et al. describe an uncertainty-quantification approach to characterize models of geophysical flows (e.g., TITAN2D) and analyze the contribution of each force term (e.g., gravity, bed friction) to the outputs. They present the method by comparing three rheology assumptions, across a wide range of flow regimes, in the case study of a block-and-ash flow propagating on the SW slope of Volcán de Colima (Mexico).

Clarke et al. present a comprehensive procedure for PVHA of PDCs; from primary field-data collection, analysis and interpretation, to the physical/statistical modeling required for uncertainty quantification. The method is applied to Aluto volcano (Ethiopia) but is transferable to other volcanic systems. A basic understanding of past eruptions remains crucial to design and justify the modeling strategy but initial PVHA of PDCs may be possible at data-scarce volcanoes, if supported by data from analogue volcanoes.

Spiller et al. introduce a probabilistic model for the cessation of PDC activity that accounts for the time elapsed from the last PDC. They combine this model with a structured and reproducible uncertainty quantification framework that allows robust, yet rapid, PVHA using observational data for dome-collapse PDCs, numerical simulations of TITAN2D and Gaussian process emulators. The method is applied to a hiatus in volcanic activity, or post-eruption unrest context, at Soufrière Hills Volcano, Montserrat.

In conclusion, we suggest that increased connections between the PDC/lahar scientific communities worldwide will result in further advances in the field. We believe that future hazard assessments will require enhanced multi- and inter-disciplinarity among volcano scientists; continuous communication and mutual learning between observational volcanology and physical/statistical modeling aimed at simulating eruptive scenarios and/or quantifying uncertainty in PVHA (Figure 1B).

\section{AUTHOR CONTRIBUTIONS}

All authors contributed significantly to the writing of the manuscript and approved it for publication. PT generated the figures.

\section{FUNDING}

This work has been supported by Global Geological Risk Platform of the British Geological Survey NC-ODA grant NE/R000069/1: Geoscience for Sustainable Futures.

\section{ACKNOWLEDGMENTS}

We warmly thank Valerio Acocella for having encouraged us to submit this Research Topic and for all his support throughout. 
We are extremely grateful to Eliza Calder for her contributions to the Research Topic before she had to, unfortunately, withdraw from the editing team. We sincerely thank Fabio Dioguardi for his invaluable work as convener of the session at Cities on Volcanoes 10 , which directly resulted in the preparation of this Research Topic. We also thank a number of colleagues for very fruitful conversations about the science covered in the aforementioned session and in this Research Topic: Jonathan Procter, Sylvain Charbonnier, Abani Patra, Augusto Neri, Tomaso Esposti Ongaro, Greg Valentine, Sue Loughlin, Ben Clarke, Domenico

\section{REFERENCES}

Aspinall, W. P., Woo, G., Voight, B., and Baxter, P. J. (2003). Evidence-based volcanology: application to eruption crises. J. Volcanol. Geotherm. Res. 128, 273-285. doi:10.1016/s0377-0273(03)00260-9

Auker, M., Sparks, R., Siebert, L., Crosweller, H., and Ewert, J. (2013). A statistical analysis of the global historical volcanic fatalities record. J. Appl. Volcanol. 2, 2. doi:10.1186/2191-5040-2-2

Baxter, P. J., Boyle, R., Cole, P., Neri, A., Spence, R., and Zuccaro, G. (2005). The impacts of pyroclastic surges on buildings at the eruption of the Soufriere Hills volcano, Montserrat. Bull. Volcanol. 67, 292-313. doi:10.1007/s00445-0040365-7

Baxter, P. J., Jenkins, S., Seswandhana, R., Komorowski, J. C., Dunn, K., Purser, D., et al. (2017). Human survival in volcanic eruptions: thermal injuries in pyroclastic surges, their causes, prognosis and emergency management. Burns 43, 1051-1069. doi:10.1016/j.burns.2017.01.025

Bayarri, M. J., Berger, J. O., Calder, E. S., Dalbey, K., Lunagomez, S., Patra, A. K., et al. (2009). Using statistical and computer models to quantify volcanic hazards. Technometrics 51, 402-413. doi:10.1198/tech.2009.08018

Bayarri, M. J., Berger, J. O., Calder, E. S., Patra, A. K., Pitman, E. B., Spiller, E. T., et al. (2015). Probabilistic quantification of hazards: a methodology using small ensembles of physics-based simulations and statistical surrogates. Int. J. Uncertain. Quantif. 5, 297-325. doi:10.1615/Int.J.UncertaintyQuantification.2015011451

Bevilacqua, A., Patra, A. K., Bursik, M. I., Pitman, E. B., Macías, J. L., Saucedo, R., et al. (2019). Probabilistic forecasting of plausible debris flows from Nevado de Colima (Mexico) using data from the Atenquique debris flow, 1955. Nat. Hazards Earth Syst. Sci. 19 (4), 791-820. doi:10.5194/nhess-19-791-2019

Branney, M. J., and Kokelaar, B. P. (2002). Pyroclastic density currents and the sedimentation of ignimbrites. Piccadilly, United Kingdom: Geological Society of London, Vol. 2.

Brown, S. K., Jenkins, S. F., Sparks, R. S. J., Odbert, H., and Auker, M. R. (2017). Volcanic fatalities database: analysis of volcanic threat with distance and victim classification. J. Appl. Volcanol. 6, 1-20. doi:10.1186/s13617-017-0067-4

Cioni, R., Tadini, A., Gurioli, L., Bertagnini, A., Mulas, M., Bevilacqua, A., et al. (2020). Estimating eruptive parameters and related uncertainties for pyroclastic density currents deposits: worked examples from Somma-Vesuvius (Italy). Bull. Volcanol. 82, 65. doi:10.1007/s00445-020-01402-7

Connor, C. B., Hill, B. E., Winfrey, B., Franklin, N. M., and Femina, P. C. L. (2001). Estimation of volcanic hazards from tephra fallout. Nat. Hazards Rev. 2, 33-42. doi:10.1061/(asce)1527-6988(2001)2:1(33)

Dellino, P., Dioguardi, F., Doronzo, D. M., and Mele, D. (2019). The rate of sedimentation from turbulent suspension: an experimental model with application to pyroclastic density currents and discussion on the grain-size dependence of flow runout. Sedimentology 66, 129-145. doi:10.1111/sed.12485

Dufek, J. (2016). The fluid mechanics of pyroclastic density currents. Annu. Rev. Fluid Mech. 48, 459-485. doi:10.1146/annurev-fluid-122414-034252

Dufek, J., Esposti Ongaro, T., and Roche, O. (2015). "Pyroclastic density currents: processes and models," in The encyclopedia of volcanoes. 2nd Edn. Editors H. Sigurdsson, B. Houghton, S. McNutt, H. Rymer, and J. Stix (Cambridge, United Kingdom: Academic Press), 617-629. doi:10.1016/B978-0-12-385938-9.00035-3

Hyman, D. M., Bevilacqua, A., and Bursik, M. I. (2019). Statistical theory of probabilistic hazard maps: a probability distribution for the hazard boundary location. Nat. Hazards Earth Syst. Sci. 19, 1347-1363. doi:10.5194/nhess-19-1347-2019
Doronzo, Sarah Ogburn, Mark Woodhouse, Matteo Trolese and others. Last but not least, we wholeheartedly thank all the authors that have contributed to the Research Topic, all the reviewers and editors that have freely dedicated their precious time to improve the clarity and/or quality of the research presented, and the support team of Frontiers in Earth Science, in particular Ursula Rabar, for supporting us throughout the process of preparing and completing this Research Topic. Published with permission of the Executive Director of British Geological Survey (NERC-UKRI).

Iverson, R. M. (1997). The physics of debris flows. Rev. Geophys. 35, 245-296. doi:10.1029/97rg00426

Jenkins, S. F., Phillips, J. C., Price, R., Feloy, K., Baxter, P. J., Hadmoko, D. S., et al. (2015). Developing building-damage scales for lahars: application to Merapi volcano, Indonesia. Bull. Volcanol. 77, 75. doi:10.1007/s00445-015-0961-8

Manville, V., Németh, K., and Kano, K. (2009). Source to sink: a review of three decades of progress in the understanding of volcaniclastic processes, deposits, and hazards. Sediment. Geol. 220, 136-161. doi:10.1016/j.sedgeo.2009.04.022

Marzocchi, W., and Bebbington, M. S. (2012). Probabilistic eruption forecasting at short and long time scales. Bull. Volcanol. 74, 1777-1805. doi:10.1007/s00445-012-0633-x

Marzocchi, W., Sandri, L., Gasparini, P., Newhall, C., and Boschi, E. (2004). Quantifying probabilities of volcanic events: the example of volcanic hazard at Mount Vesuvius. J. Geophys. Res. 109, B11201. doi:10.1029/2004JB003155

Mead, S. R., and Magill, C. R. (2017). Probabilistic hazard modelling of raintriggered lahars. J. Appl. Volcanol. 6, 8. doi:10.1186/s13617-017-0060-y

Mead, S., Magill, C., and Hilton, J. (2016). Rain-triggered lahar susceptibility using a shallow landslide and surface erosion model. Geomorphology 273, 168-177. doi:10.1016/j.geomorph.2016.08.022

Neri, A., Bevilacqua, A., Esposti Ongaro, T., Isaia, R., Aspinall, W. P., Bisson, M., et al. (2015). Quantifying volcanic hazard at Campi Flegrei caldera (Italy) with uncertainty assessment: 2. Pyroclastic density current invasion maps. J. Geophys. Res. Solid Earth 120, 2330-2349. doi:10.1002/2014jb011776

Newhall, C., and Hoblitt, R. (2002). Constructing event trees for volcanic crises. Bull. Volcanol. 64, 3-20. doi:10.1007/s004450100173

Pallister, J., Papale, P., Eichelberger, J., Newhall, C., Mandeville, C., Nakada, S., et al. (2019). Volcano observatory best practices (VOBP) workshops-a summary of findings and best-practice recommendations. J. Appl. Volcanol. 8, 2. doi:10. 1186/s13617-019-0082-8

Pierson, T. C., and Major, J. J. (2014). Hydrogeomorphic effects of explosive volcanic eruptions on drainage basins. Annu. Rev. Earth Planet. Sci. 42, 469-507. doi:10.1146/annurev-earth-060313-054913

QGIS Development Team (2021). QGIS geographic information system. Available at: http://qgis.osgeo.org Accessed January 27, 2021.

Rutarindwa, R., Spiller, E. T., Bevilacqua, A., Bursik, M. I., and Patra, A. K. (2019). Dynamic probabilistic hazard mapping in the Long Valley volcanic region CA: integrating vent opening maps and statistical surrogates of physical models of pyroclastic density currents. J. Geophys. Res. Solid Earth 124, 9600-9621. doi:10.1029/2019jb017352

Sandri, L., Jolly, G., Lindsay, J., Howe, T., and Marzocchi, W. (2012). Combining longand short-term probabilistic volcanic hazard assessment with cost-benefit analysis to support decision making in a volcanic crisis from the Auckland volcanic field, New Zealand. Bull. Volcanol. 74, 705-723. doi:10.1007/s00445-011-0556-y

Sandri, L., Thouret, J. C., Constantinescu, R., Biass, S., and Tonini, R. (2014). Longterm multi-hazard assessment for El Misti volcano (Peru). Bull. Volcanol. 76, 1-26. doi:10.1007/s00445-013-0771-9

Sandri, L., Tierz, P., Costa, A., and Marzocchi, W. (2018). Probabilistic hazard from pyroclastic density currents in the Neapolitan area (Southern Italy). J. Geophys. Res. Solid Earth 123, 3474. doi:10.1002/2017JB014890

Sparks, R. S. J., and Aspinall, W. P. (2004). Volcanic activity: Frontiers and challenges in forecasting, prediction and risk assessment. IUGG 19, 359-373. doi:10.1029/150gm 28

Sparks, R. S. J., Wilson, L., and Hulme, G. (1978). Theoretical modeling of the generation, movement, and emplacement of pyroclastic flows by column collapse. J. Geophys. Res. 83 (B4), 1727-1739. doi:10.1029/JB083iB04p01727 
Spiller, E. T., Bayarri, M. J., Berger, J. O., Calder, E. S., Patra, A. K., Pitman, E. B., et al. (2014). Automating emulator construction for geophysical hazard maps. SIAM-ASA J. Uncertain. Quantif. 2, 126-152. doi:10.1137/ 120899285

Sulpizio, R., Dellino, P., Doronzo, D. M., and Sarocchi, D. (2014). Pyroclastic density currents: state of the art and perspectives. J. Volcanol. Geotherm. Res. 283, 36-65. doi:10.1016/j.jvolgeores.2014.06.014

Thouret, J. C., Antoine, S., Magill, C., and Ollier, C. (2020). Lahars and debris flows: characteristics and impacts. Earth-Sci. Rev. 201, 103003. doi:10.1016/j.earscirev. 2019.103003

Tierz, P. (2020). Long-term probabilistic volcanic hazard assessment using open and non-open data: observations and current issues. Front. Earth Sci. 8, 257.

Tierz, P., Loughlin, S. C., and Calder, E. S. (2019). VOLCANS: an objective, structured and reproducible method for identifying sets of analogue volcanoes. Bull. Volcanol. 81, 76. doi:10.1007/s00445-019-1336-3

Tierz, P., Sandri, L., Costa, A., Sulpizio, R., Zaccarelli, L., Vito, M. A. D., et al. (2016). "Uncertainty assessment of pyroclastic density currents at Mount Vesuvius (Italy) simulated through the energy cone model," in Natural hazard uncertainty assessment: modeling and decision support. Editors P. Webley, K. Riley, and M. P. Thompson (Hoboken, NJ: John Wiley \& Sons), 125-145. doi:10.1002/9781119028116.ch9

Tierz, P., Stefanescu, E. R., Sandri, L., Sulpizio, R., Valentine, G. A., Marzocchi, W., et al. (2018). Towards quantitative volcanic risk of pyroclastic density currents: probabilistic hazard curves and maps around Somma-Vesuvius (Italy). J. Geophys. Res. Solid Earth 123-383. doi:10.1029/2017JB015383

Tierz, P., Woodhouse, M. J., Phillips, J. C., Sandri, L., Selva, J., Marzocchi, W., et al. (2017). A framework for probabilistic multi-hazard assessment of rain-triggered lahars using bayesian belief networks. Front. Earth Sci. 5, 73. doi:10.3389/feart.2017.00073

Valentine, G. A. (1998). Damage to structures by pyroclastic flows and surges, inferred from nuclear weapons effects. J. Volcanol. Geotherm. Res. 87, 117-140. doi:10.1016/s0377-0273(98)00094-8

Vallance, J. W., and Iverson, R. M. (2015). "Lahars and their deposits," in The encyclopedia of volcanoes. 2nd Edn. Editors H. Sigurdsson, B. Houghton, S. McNutt, H. Rymer, and J. Stix (Cambridge, United Kingdom: Academic Press), 649-664. doi:10.1016/B978-0-12-385938-9.00037-7

Woo, G. (1999). The mathematics of natural catastrophes. London, United Kingdom: Imperial College Press.

Conflict of Interest: The authors declare that the research was conducted in the absence of any commercial or financial relationships that could be construed as a potential conflict of interest.

British Geological Survey (c) UKRI 2021. This is an open-access article distributed under the terms of the Creative Commons Attribution License (CC BY). The use, distribution or reproduction in other forums is permitted, provided the original author(s) and the copyright owner(s) are credited and that the original publication in this journal is cited, in accordance with accepted academic practice. No use, distribution or reproduction is permitted which does not comply with these terms. 